\title{
The Origin of Tar Al-Say'ed and Tar Al-Najaf, Karbala-Najaf Vicinity, Central Iraq
}

\author{
Varoujan K. Sissakian ${ }^{1}$, Mawahib F. Abdul Jab'bar ${ }^{2}$, Nadhir A. Al-Ansari ${ }^{3}$ and Sven Knutsson ${ }^{3}$ \\ 1. Private consultant geologist, Erbil 14006, Iraq \\ 2. State Company of Geological Survey and Mining, Baghdad 14001, Iraq \\ 3. Department of Civil, Environmental and Natural Resources Engineering, Lulea University of Technology, Lulea 97187, Sweden
}

\begin{abstract}
In central part of Iraq within the vicinity of Karbala-Najaf, two cliffs called "Tar Al-Say'ed" and "Tar Al-Najaf” form conspicuous geomorphological forms between the Mesopotamia Plain and the Western and Southern Deserts. The top surface between the two cliffs (tars) is covered by alluvial fan sediments, laid down by Al-Khir Valley when merging in a large depression due to the drop in the gradient of the valley. Consequently, the depression was divided into two parts, to the left is called Al-Razzazah Depression, whereas to the right is called Bahir Al-Najaf. This affected the course of the River Euphrates. The deposition stopped due to an uplift movement which caused the elevation of the two cliffs which are covered by alluvial fan sediments. The two cliffs had and are still suffering from retreating, due to lateral erosion by wave actions in Al-Razzazah Depression. Springs located along a straight line, sag pond, deflected drainage, shutter ridges and pressure ridges can be noticed in the area. The age of both cliffs is estimated to be upper Late Pleistocene-early Holocene.
\end{abstract}

Key words: Neotectonic, erosional cliff, alluvial fan, Pleistocene, Iraq.

\section{Introduction}

Tar Al-Say'ed and Tar Al-Najaf are two conspicuous geomorphological outstanding features in Karbala-Najaf vicinity (Fig. 1). "Tar" is a local name for a cliff. Tar Al-Say'ed and Tar Al-Najf form elongated and steep cliffs with NE-SW and NW-SE trends, respectively, meeting at appoint called "Al-Lisan" area, which forms the head of a triangle formed by the two cliffs, whereas the base of the triangle is a flat area, forming the boundary between the flat Mesopotamia Plain and gently sloping plain of the Karbala-Najaf Alluvial Fan.

The length of Tar Al-Say'ed and Tar Al-Najaf is $105.1 \mathrm{~km}$ and $103.4 \mathrm{~km}$, respectively. They form the boundaries of a large alluvial fan with typical delta shape and flat top, and the length of the top covered the alluvial fan is $64 \mathrm{~km}$, with coverage area of $2761 \mathrm{~km}^{2}$. It

Corresponding author: Nadhir A. Al-Ansari, professor, research fields: water resources and environmental engineering. E-mail: nadhir.alansari@1tu.se. is originated from Al-Khir Valley, with SW-NE trend, starting from the Saudi Arabia, being one of the largest valleys in the Iraqi Southern Desert (Fig. 1) [1]. To the left of Tar Al-Najaf is the Al-Razzazah Depression, or Lake Milih into which excess water from the Euphrates River is diverted by a controlled escape channel or canal. The lake is rather shallow and water levels change with the seasons. The lake was created in 1969 when a Spanish contractor built a drainage canal to divert the annual floodwaters of the Euphrates River into the desert to prevent flooding across southern Iraq [2].

A number of researchers had executed some work on the studied area and its surroundings, but none of them dealt with the origin of the two cliffs. Most related studies are mentioned hereinafter:

- Ghalib [1] mentioned that the area covered by the two cliffs is built-up by the Dibdibba Formation, representing a very large alluvial fan;

- Hamza [3], in the geomorphological map of Iraq, mentioned the presence of gypcrete covering the involved area, but did not refer to the alluvial fan; 


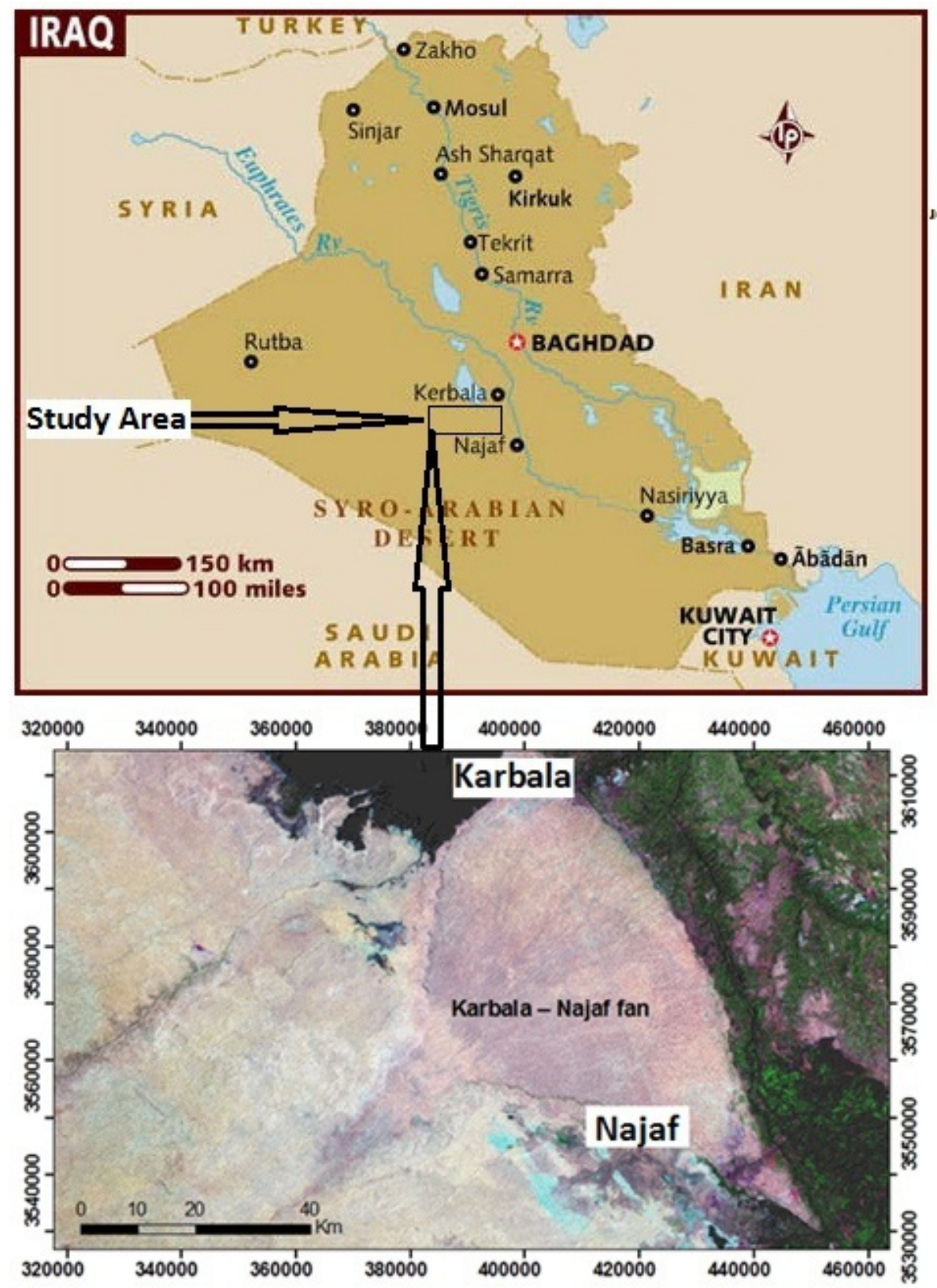

Fig. 1 Landsat 7 image of Karbala-Najaf Plateau, top covered by gypcrete.

- Barwari et al. [4], in the Quaternary Sediments Map of Iraq, also referred to the gypcrete that covers the top surface area, without referring to the origin of the cliffs;

- Sissakian and Ibrahim [5], in the geological hazards map of Iraq, mentioned about the gypcrete covering the top surface area and about the active mass movements acting along the two cliffs, without referring to their origin;
- Al-Khateeb and Hassan [6] carried out detailed geological mapping in the involved area, and they defined the exposed geological formations;

- Fouad [7-9] and Fouad and Sissakian [10] did not mention about the origin of the two cliffs when reporting about the structural and tectonic evolution of the Iraqi Western Desert and the Mesopotamia Foredeep, respectively, neither mentioned about the presence nor otherwise surface faults, near the two 
cliffs, except the active Abu Jir-Euphrates Tectonic Zone;

- Yacoub [11] did not mention about the origin of the cliffs during reporting about the geomorphology of the Mesopotamia Plain.

The aim of this study is to explain the origin of the two cliffs and discuss their evolution, using mainly Landsat, Google Earth and DEM (digital elevation model) images, with collaboration of field and historical data.

\section{Materials and Method}

To achieve the aim of this study, the following materials were used:

- geological maps (scale of 1:100,000, 1:250,000 and 1:1,000,000);

- topographical maps (scale of 1:100,000 and 1:250,000);

- Google Earth, DEM and satellite images (Fig. 2);

- relevant published articles and theses.

The geological and topographical maps with the Google Earth, DEM and satellite images were used to recognize the present indications of the origin of the two cliffs. Field description points in different geological reports, historical and relevant scientific published articles were reviewed to get an idea about the origin of the two cliffs. Some structural data were also reviewed to elucidate the relation between the subsurface geology and the existing two cliffs.

Within GIS (Geographic Information System) and DEM applications, spatial analysis and hydrological tools of ArcGIS were used to prepare many maps for the studied area, such as elevation map and slope map in addition to 3D image. The simplest morphological analysis involved the study of the elevation data. In the present approach, DEMs (Fig. 2) were displayed for visual inspection as grey-scale images, 3D surface views and shaded relief models or as combinations of these. The shaded relief model was a key component throughout this study because it was the most suitable terrain model for the recognition and interpretation of complex morphological features. Vertical exaggeration of elevations was used to enhance the study of subtle features in flat basin areas, and cross-sections were generated along topographical sections to study slope and slope curvature conditions using 3D analyst extension.

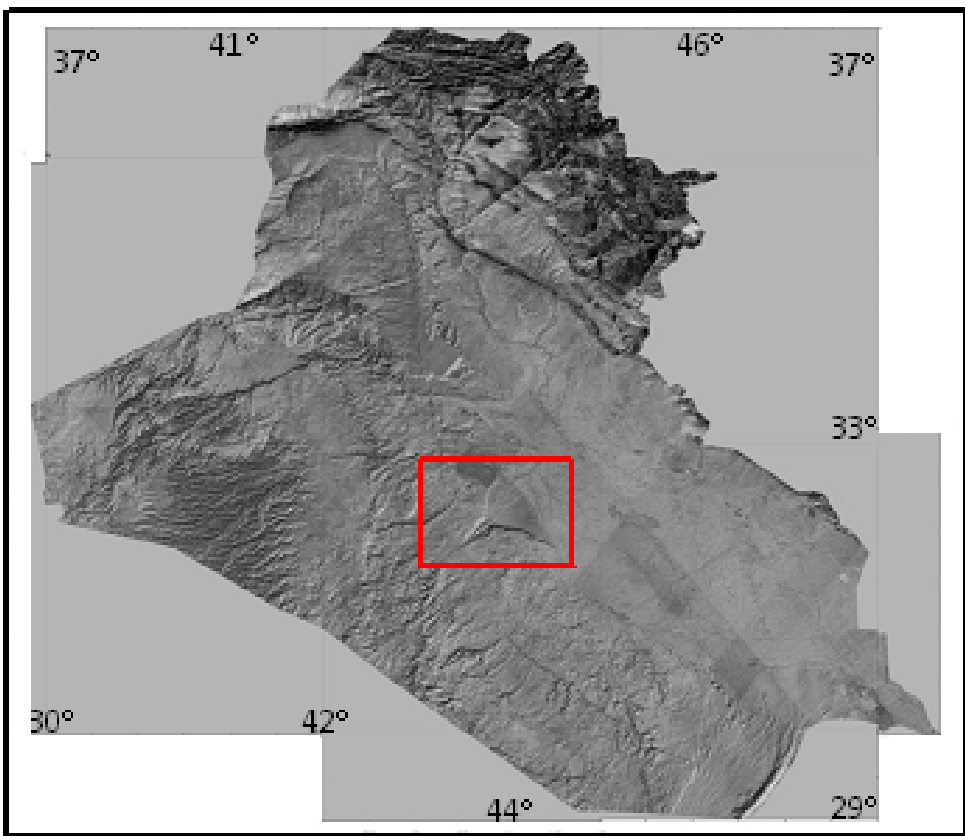

Fig. 2 DEM image showing the studied area. 


\section{Geological Setting}

The geology of the involved area is described briefly hereinafter. It includes: geomorphology, structure and tectonics, stratigraphy and hydrogeology depending on Refs. [6, 12-15].

\subsection{Geomorphology}

The two cliffs are the most significant geomorphological feature in the involved area, forming erosional ridges suffering from different types of mass movements. In between the ridges, the area is covered by a very large alluvial fan of one stage [16], developed by Al-Khir Valley, and the apex of the fan is at Al-Lisan area. The gravels of the fan range in size from $1 \sim 2 \mathrm{~cm}$, with a thickness varying from $8 \sim 14 \mathrm{~m}$, composed mainly by silicates and carbonates [6]. Top of the alluvial fan is a flat area sloping NE wards, covered by thick gypcrete with a high percentage of fine sand.

Large valleys run on both sides of the fan, those on the left side drain in the Razzazah depression, whereas those on the right side drain in Bahr Al-Najaf depression (also called Bahr Al-Milih). Both depressions are very wide. The latter is shallow almost dry, except in the rainy seasons. Whereas, the former includes water derived from the Euphrates River and tens of springs. Both depressions are bounded by sabkha sediments.

\subsection{Tectonics and Structure}

The involved area is located within the Inner Platform and the Outer Platform of the Arabian Plate $[8,13]$. The contact between the two platforms passes in the apex area of the fan. Consequently, the two cliffs are located within the Outer Platform represented by the Mesopotamia Foredeep, its western margins, whereas, the extreme part of the studied area is located within the Inner Platform. According to Fouad [8], no surface faults occur near the two cliffs. However, the Abu Jir-Euphrates Fault Zone passes in the western part of the studied area. The presence of tens of springs is good indication for this active tectonic zone.

\subsection{Stratigraphy}

The exposed geological formations and present Quaternary sediments (Fig. 3) are briefly mentioned, hereinafter.

3.3.1 Dammam Formation, Upper Member (Late Eocene)

Only the upper member of the Dammam Formation is exposed in the studied area. The upper member consists of thickly bedded limestone: some beds include small nummulites, with marl intercalations and very rare chert lenses.

\subsubsection{Euphrates Formation (Early Miocene)}

The formation consists of basal conglomerate and/or breccia, followed upwards by fossiliferous limestone, dolostone with some marl intercalations. The pebbles of the conglomerate are derived from the underlying Dammam Formation, the size of the pebbles ranges from $<0.1 \sim 1.5 \mathrm{~m}$.

3.3.3 Nfayil Formation, Lower Member (Middle Miocene)

Only the lower member of the Nfayil Formation is exposed in the studied area. The upper member consists of three sedimentary cycles. Each cycle consists of green marl overlain by limestone. The limestone of the second cycle includes large oyster shells.

\subsubsection{Dibdibba Formation (Pliocene-Pleistocene)}

The formation consists of coarse and white sandstone and rare conglomerate.

\subsubsection{Quaternary Sediments}

Different types of Quaternary sediments are developed in the studied area, like gypcrete, sabkha, sand dunes, alluvial fan, flood plain, depression fill, and valley fill sediments. However, the gypcrete is the most widely developed and covers the majority of the Karbala-Najaf Alluvial Fan. The fan is originated from Al-Khir Valley. Its length is $64 \mathrm{~km}$ with SW-NE trend. The size of the gravels of the fan ranges from $1 \sim 2 \mathrm{~cm}$, 


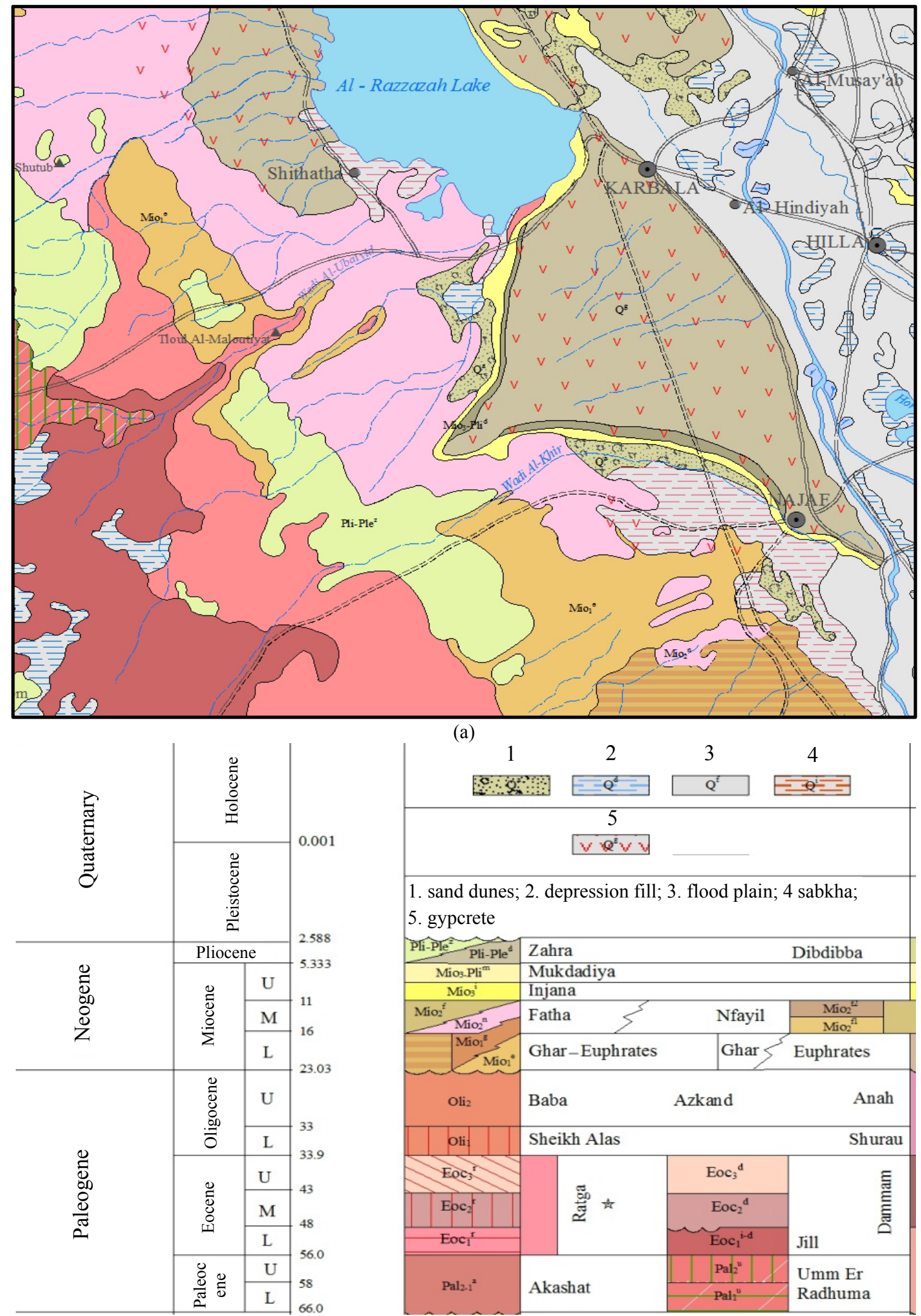

(b)

Fig. 3 Geological map of the studied area (after Ref. [14]): (a) exposed geological formation; (b) stratigraphic column (U: upper, M: middle, L: lower). Note the abnormal exposures pattern of the Dammam, Euphrates, Nfayil and Zahra Formations, along and south of Al-Ubayidh Valley. 
with a thickness varying from $8 \sim 14 \mathrm{~m}$. The gravels consist of silicates and carbonates [6]. The depression fill sediments consist of clay and fine silt, contaminated by organic materials and locally by Aeolian sand, which are present in two forms: sand dunes and nabkhas. The sand dunes are accumulated in the depression, which is formed due to the Abu Jir-Euphrates Fault Zone. The dunes are of Barchan type, with height of $0.5 \sim 2 \mathrm{~m}$, the sand consists mostly of fine grains of clay in form of very fine rolled balls, with very rare quartz grains.

\subsection{Hydrogeology}

The groundwater on the top of the area between the two cliffs is of fresh and bicarbonate type, its depth ranges from $8 \sim 15 \mathrm{~m}$, whereas in the western and southern parts of the studied area, the groundwater is of sulphatic type and has artesian character, as it is evidenced by tens of springs, which yield highly sulphatic water. The springs are related to the active Abu Jir-Euphrates Fault Zone, which passes west and south of the two cliffs, forming wide depression called Bahr Al-Najaf. The depth of the depression ranges from $<1 \sim 3 \mathrm{~m}$, whereas its width ranges from $<1 \sim 30 \mathrm{~km}$, the maximum width is west of Najaf city (Fig. 3), with a very shallow groundwater level.

\section{Tar Al-Say'ed and Tar Al-Najaf}

The dimensions and characteristics of both cliffs, Tar Al-Say'ed and Tar Al-Najaf, are mentioned hereinafter.

\subsection{Tar Al-Say'ed}

It is the cliff formed along the left side of the Karbala-Najaf Alluvial Fan (Figs. 1, 2 and 4). The length of the cliff is $105.1 \mathrm{~km}$, maximum height difference along the cliff is $21.7 \mathrm{~m}$, its direction is NE-SW with clear circular inclination towards NNE in its extreme part, near Karbala city (Figs. 3 and 4). The exposed rocks along the cliff belong to the Nfayil, Injana and Dibdibba Formations, whereas the top surface area is covered by gypcrete, forming the top layer of the alluvial fan.

In the extreme northeastern end of the cliff, exactly west of Karbala town, there is a crescent shape bulge, towards inside of the cliff (Figs. 3 and 4). The authors

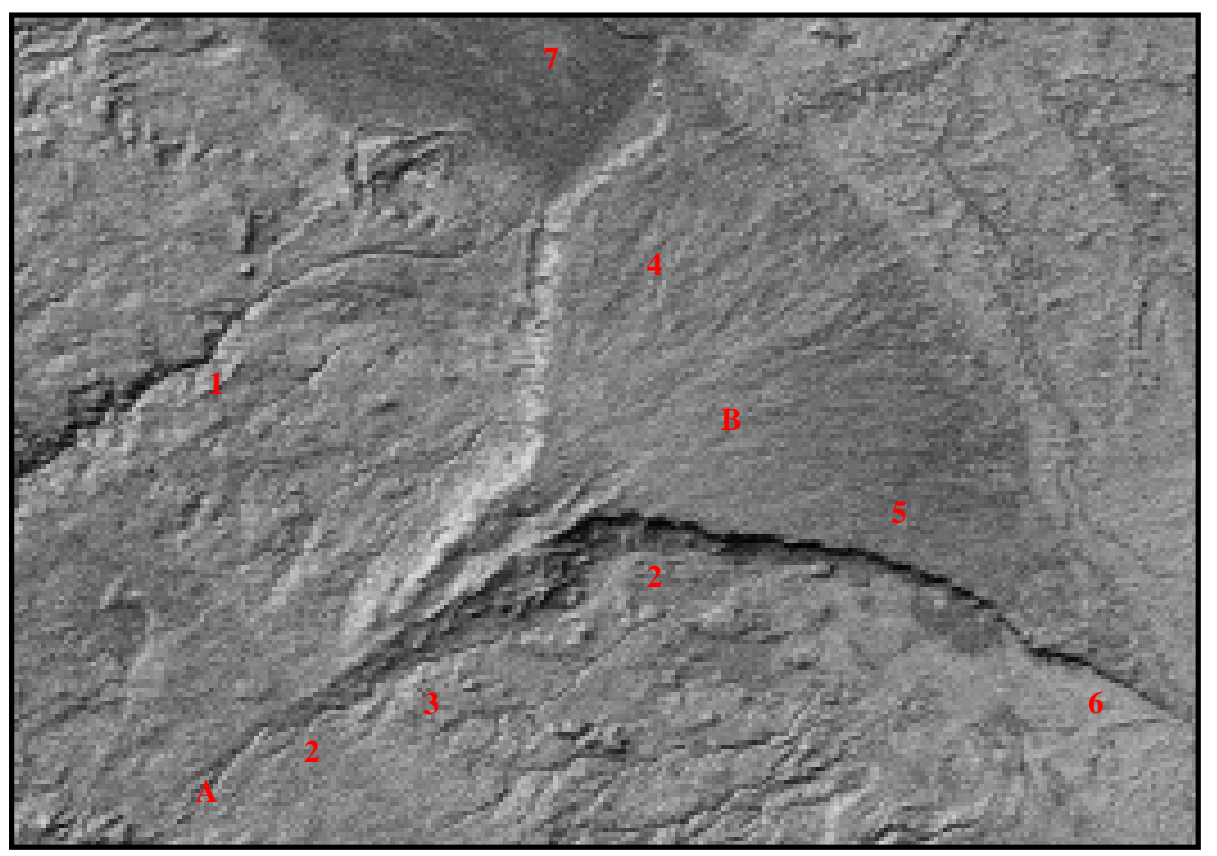

Fig. 4 DEM image showing the alluvial fan and both cliffs (wadi: 1. Al-Ubaidh; 2. Al-Khir; 3. Al-Lisan area. Tar: 4. Al-Say'ed; 5. Al-Najaf; 6. Bahr Al-Najaf; 7. Al-Razzazah Lake. A to B = lineament). 


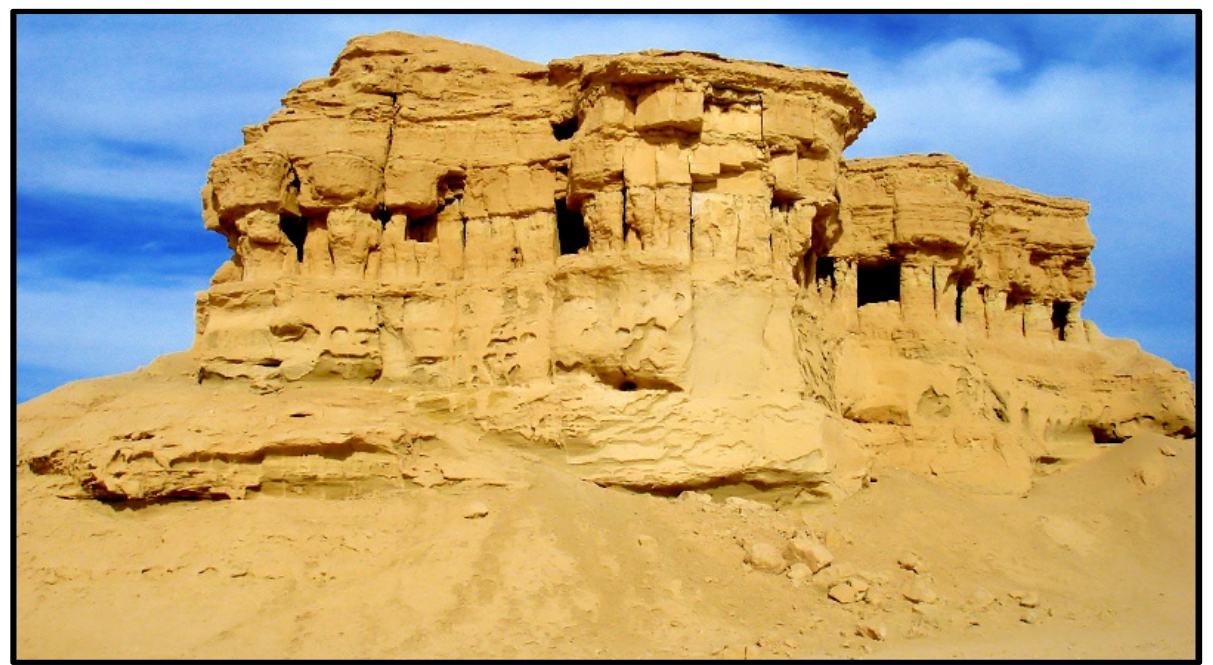

Fig. 5 Caving in Tar Al-Say'ed (archeological site). Note the toppled blocks and the blocky nature of the exposed rocks.

believe that it is formed due to undercut erosion of Al-Razzazah Lake and continuous collapsing of the rocks along the cliff at the involved area. However, the whole cliff suffers from active mass movement, especially toppling of large blocks and caving, which form archeological site (Fig. 5).

\subsection{Tar Al-Najaf}

It is the cliff formed along the right side of the Karbala-Najaf Alluvial Fan (Figs. 1, 2 and 4). The length of the cliff is $103.4 \mathrm{~km}$, maximum height difference along the cliff is $21.5 \mathrm{~m}$, and its direction is NW-SE, with clear circular inclination towards SSE in its extreme part, near Najaf city (Figs. 3 and 4). The exposed rocks along the cliff belong to the Nfayil, Injana and Dibdibba Formations, whereas the top surface area is covered by gypcrete, forming the top layer of the alluvial fan.

\subsection{Symmetry}

The Karbala-Najaf Alluvial Fan has typical fan shape: such shape is mentioned by Bull [17] and Ritter et al. [18], with clear symmetrical form. However, the fan has lost its symmetry especially in its distal parts, along the ends of both cliffs (Figs. 3 and 4) due to head ward erosion (see Section 5). However, its distal part is now in the form of a straight line and has lost its crescent form due to erosion of the Euphrates River
(ShatAl-Hilla) and interfingering of the alluvial fan sediments with the flood plain sediments of the river. Moreover, the concave shape of the top surface is also vanished (Fig. 6), due to peneplanation processes and cultivation activities. Both cliffs have almost the same slope (Fig. 6), which is almost in a vertical form, which decreases towards the apex area.

The three constructed topographic profiles $(2,3$ and 4 in Fig. 6) demonstrate the morphology of the fan. Profile No. 2 still shows the concave form of the top surface of the fan. With almost vertical cliffs, Profile No. 3 shows a steep slope on both cliffs with clear indication for the old course of the main feeder channel. Profile No. 4 shows a comparatively less gentle slope on both cliffs, with very clear indication for the location and depth of the old course of the main feeder channel (Al-Lissan area). Whereas, the gradient of the fan is shown in Profile No. 1 , which is about $0.19 \%$.

\section{Discussions}

The origin of both Tar Al-Say'ed and Tar Al-Najf is discussed hereinafter, using DEM and Landsat images, geological evidences and historical data.

\subsection{Karbala-Najaf Alluvial Fan}

The Karbala-Najaf Alluvial Fan is one of the largest alluvial fans in Iraq: its length is $64 \mathrm{~km}$, the thickness 

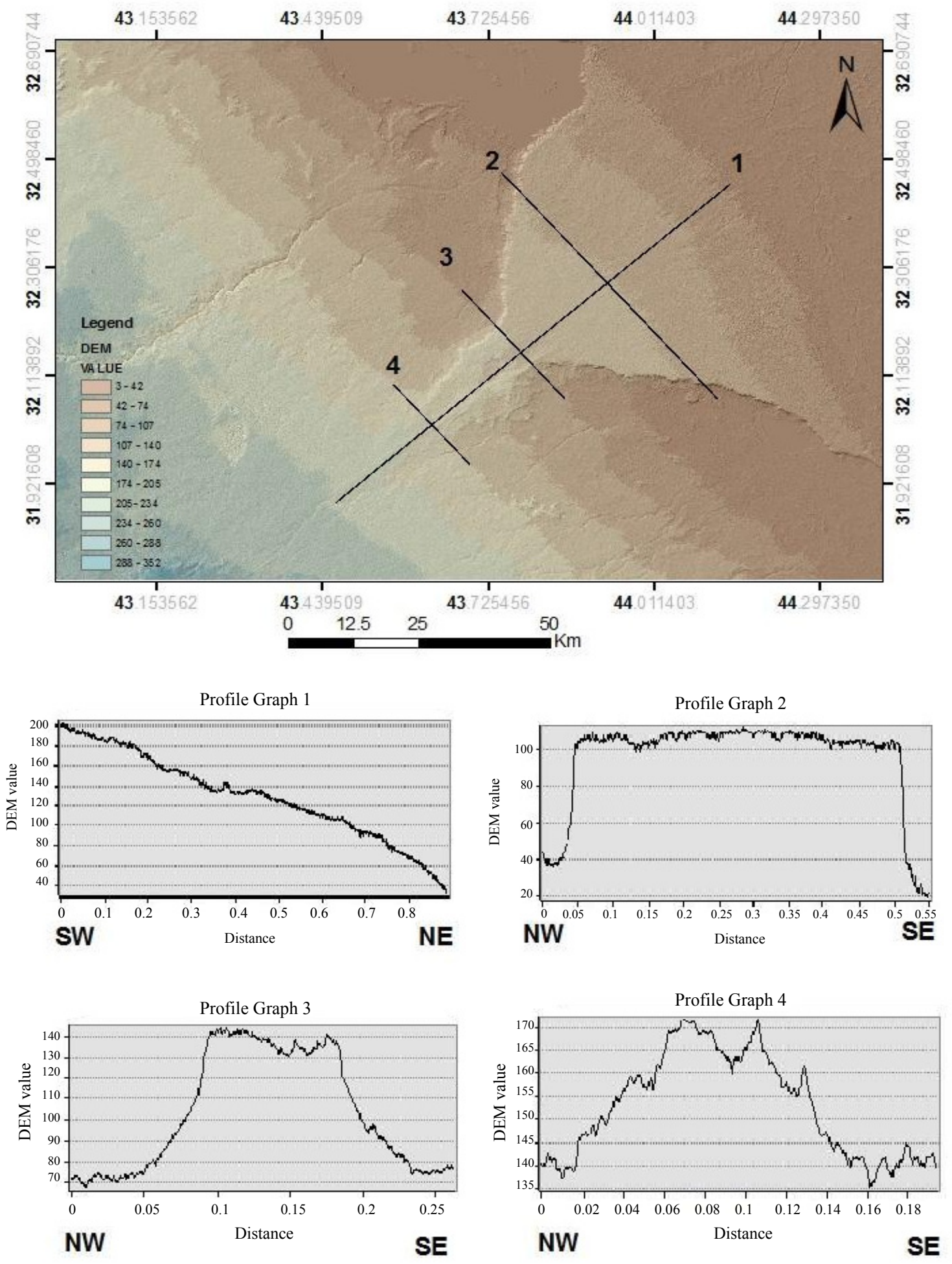

Fig. 6 Landsat image of the fan with four topographic cross sections.

of its sediments ranges from $8 \sim 14 \mathrm{~m}$, composed mainly by silicates and carbonates [6]. The top of the alluvial fan is a flat area sloping NE wards, covered by thick gypcrete with a high percentage of fine sand. The rills on the surface are still clearly visible (Fig. 2).

The Karbala-Najaf Alluvial Fan was laid down by 
Al-Khir Valley, which represents the main feeder channel. The apex of the fan is at Al-Lisan area (Figs. 2-4). Since the development of a fan needs a drop in the gradient of the feeder channel, either in a mountain front or when a valley merges with a wide depression [18-21]. Therefore, the fan was originated when Al-Khir Valley was merging with a wide depression, which was originally one depression, but was divided into two parts by the originated alluvial fan. Nowadays, both depressions are called Al-Razzaza Lake, on the left, and Bahir Al-Najaf, on the right. The continuous deposition of the fan sediments had blocked the depression and divided it into two parts. This is attributed to the depth of the depression, which is less than the thickness of the alluvial fan sediments, which range in thickness from $8 \sim 14 \mathrm{~m}$. Moreover, the continuous deposition of the fan shifted the course of the Euphrates River northeast wards. The original course of the river is clearly visible in the extreme eastern part of Al-Razzazah Depression (Figs. 7 and 8).

\subsection{Evolution of Both "Tars"}

The Karbala-Najaf Alluvial Fan was deposited during Pleistocene, as the majority of the alluvial fans in the Iraqi Southern and Western Deserts [11, 22, 23]. During Late Pleistocene and/or early Holocene, a neotectonic activity caused the rising of the involved area of the alluvial fan and nearby surroundings. This is attributed to the active Abu Jir-Euphrates Tectonic Zone, which is still an active zone [7, 8]. A clear



(a)

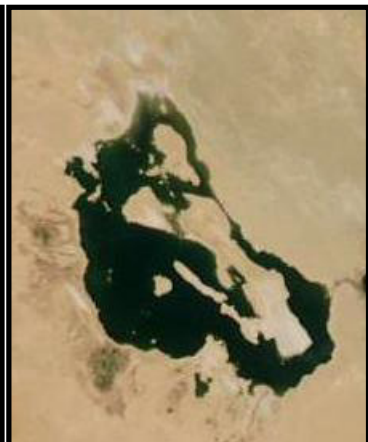

(b) lineament (Figs. 4 and 9) is still visible on the surface (A-B in Fig. 4), and it had effected on Al-Lisan area. Moreover, traces of lineaments can be still seen towards the north of the aforementioned lineament: they are clearly visible between C and D in Fig. 9.

The uplift of the area has caused the formation of the two cliffs (Tar Al-Say'ed and Tar Al-Najaf), and their heights diminish towards the end of the alluvial fan. The uplift has also shifted the course of Al-Khir Valley, the main feeder channel to its new course towards the

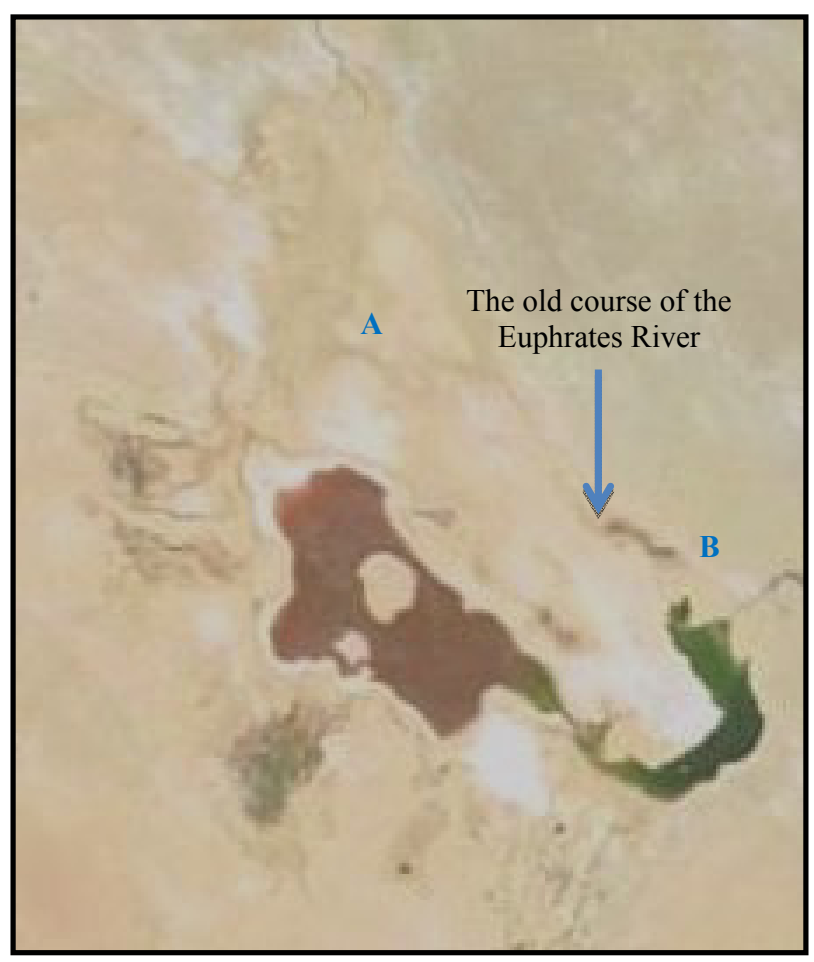

Fig. 7 Al-Razzazah Lake (depression) in 2012 (A to B is the old course of the Euphrates River, running parallel to the depression) [24].

Fig. 8 Four scenes of Al-Razzaah Lake [24, 25]: (a) 2000; (b) 2003; (c) 2008; (d) 2012. Note the separation of the ancient Euphrates River's course from Al-Razzazah Depression by longitudinal mass of rocks, as clearly seen in Figs. 8b-8d, also note the ancient course of the river. 




Fig. 9 DEM image. Note the lineaments along A-B and between C-D, E-F trace of the main feeder channel (Al-Khir Valley).

left side depression (Bahir Al-Nahaf). The traces of the feeder channel are still visible on the top surface of the alluvial fan (Fig. 9, E to F). The valley started curving inside Tar Al-Najaf, causing retreating of the cliff due to undercut erosion and collapsing of large blocks of the rocks of the Nfayil and Injana Formations, both of them have blocky nature due to well bedding and jointing of the rocks, besides the caving nature (Fig. 5).

On the right side of the Karbala-Najaf Alluvial Fan, the lineament (Fig. 9, C-D) has straightened the curved limit of the alluvial fan sediments, due to the uplift movement. Moreover, the undercut erosion of Al-Ubayidh Valley has contributed in retreating of Tar Al-Say'ed and its straightening, particularly in its extreme northeastern part, which forms the nowadays southeastern limits of Al-Razzazah Lake (Fig. 9).

\subsection{Geological Evidence}

The following geological evidence was used in the assumption of the evolution of the two cliffs due to uplifting of the area:

(1) The Dammam Formation. The Dammam Formation is exposed widely west of the involved area (Fig. 3). However, small outcrop is exposed in the base of a valley south of Al-Ubayidh Valley in form of a double plunging anticline, but it is not: it is an indication for the uplifted area, otherwise it would not be exposed in the base of the two valleys as it is the case in all other valleys in neighboring areas;

(2) The Euphrates Formation. The Euphrates Formation as well is exposed in the base of the same valley, south of Al-Ubayidh Valley, in form of a double plunging anticline (Fig. 3), but it is not: it is an indication for the uplifted area, otherwise it would not be exposed in the base of the valley as it is the case in all other valleys in neighboring areas. Moreover, the formation is exposed directly on the left bank of Al-Khir Valley, also indicating uplifting of the area;

(3) The Nfayil Formation. The Nfayil Formation is exposed around Al-Razzazah Depression and Bahir Al-Najaf Depression (Fig. 3), indicating that both depressions were previously one depression with the same exposed rocks inside and around it;

(4) The Zahra Formation. The exposure of the Zahra Formation is in a longitudinal form, with almost a straight line (Fig. 3), which may indicate the boundary of the uplifted area. And since the formation is known to be deposited in depressions; therefore, it is a good indication that, after the uplift of the area, a depression was formed towards west in which the Zahra 
Formation was deposited;

(5) Geomorphological Features. They are features indicating that both depressions were originally one depression and were separated by the development of Karbala-Najaf Alluvial Fan. The width and extension of both depressions, the location of the depression between the Mesopotamia Plain and Iraqi Western and Southern Deserts, and the valleys draining both deserts and merging in the both depressions (Figs. 1, 3, 4 and 9) are good indications that both depressions were originally one depression.

Moreover, the shifting of the main feeder channel (Al-Khir Valley) from Karbala-Najaf Alluvial Fan, which is a large, single stage fan [23], is a good indication for the uplift of the involved area, otherwise the valley would not shift its course in such oblique form to leave the alluvial fan. Being a single stage fan is a good indication for continuous deposition without any interruption in sedimentation of the fan, until the feeder channel was shifted due to the uplift. The traces of the main feeder channel are still visible on the top of the fan (Fig. 9), although the surface expressions of the fan are almost vanished due to peneplaination processes and cultivation activities. The uplift had also shifted course of the Euphrates River, too (Figs. 7 and 10 ), and the cliffs along the banks of the ancient course of the river are still clear, beside the shift of the river by the continuous development of the Karbala-Najaf Alluvial Fan.

Tens of alluvial fans (Fig. 10) were developed by the valleys that drain the Iraqi Western Deserts, indicating a drop in the gradient along an almost straight line (A-B, Fig. 10), all those alluvial fans are almost vanished by erosional processes, because they have not received more sediments, since Late Pleistocene or early Holocene. This is attributed to the uplift of the area, which had caused development of the two cliffs. However, it seems from the cliffs that the maximum uplift was near Karbala-Najaf Alluvial Fan;

(6) Tectonic and Structural Evidence. The Abu Jir-Euphrates Fault Zone, as mentioned by Fouad [7, 8], "consists of several NW-SE trending faults that extend from Anah Graben, across the Euphrates River Valley to Heet, Awasil, Abu Jir, Shithatha, along the western side of the Euphrates river through Karbala, Najaf and Samawa". He also showed: "using reflection seismic sections" that the zone consists of several steeply dipping normal faults that converge downwards. Some horizons were draped over the tip of the faults to define antiforms and/or synforms with axes parallel to the zone. He concluded that these antiforms and synforms represent positive and negative flower structures and that the presence of such structures provides conclusive evidence to the occurrence of a strike-slip movement

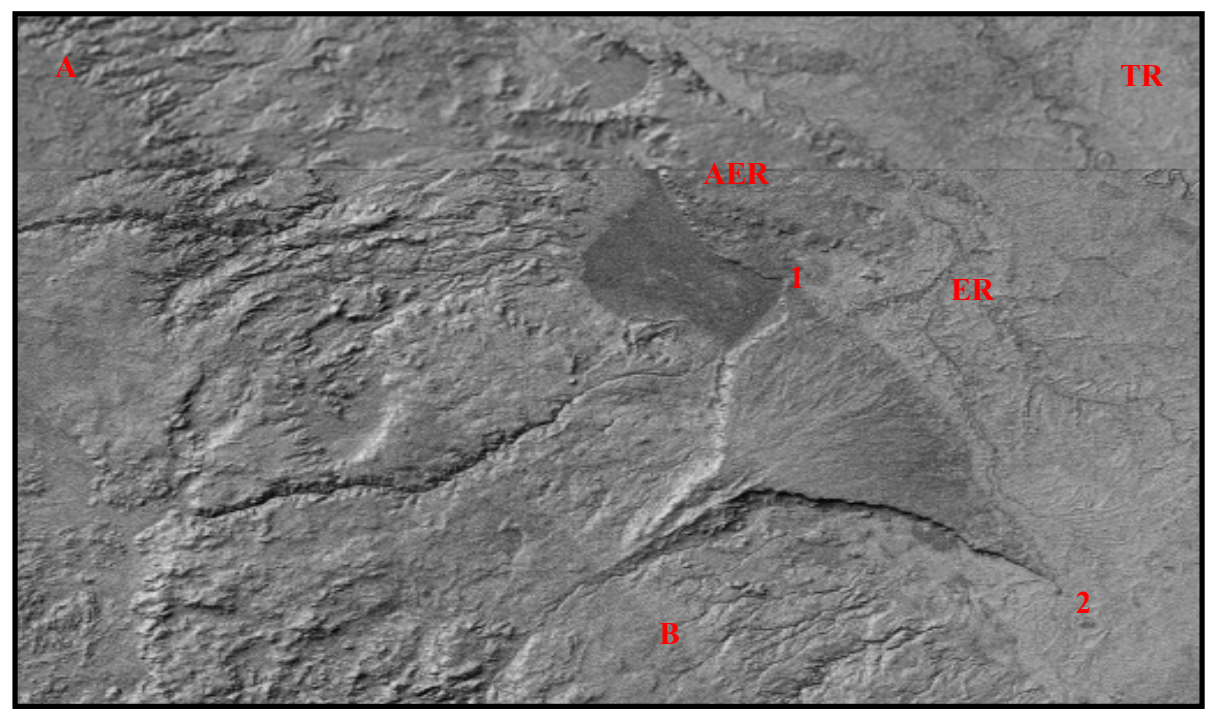

Fig. 10 DEM image showing tens of alluvial fans, west of the main Karbala-Najaf Alluvial Fan along the line A-B (TR = Tigris River, ER = Euphrates River, AER = ancient course of Euphrates River). 
along the fault zone imposed on the earlier normal one. These data may also indicate that the existence of uplifted areas along the zone, in which the Karbala-Najaf Alluvial Fan is developed, farther on sedimentation, was terminated due to the uplifting of the involved area, and consequently, Al-Khir Valley shifted its course to the drain in Bahir Al-Najaf. However, no surface rupture and/or fault line was detected in the involved areas by Al-Khateeb and Hassan [6].

Although no indication is present for offseting alluvial fan, certainly, there is a strike slip fault along Abu Jir-Euphrates Active Fault Zone [7, 8], consequently, the following forms were developed, which are good indication for tectonic activity:

- springs: tens of springs occur along the Abu Jir-Euphrates Active Fault Zone [15]. The springs are located along the A-B in Fig. 10;

- deflected drainage: Al-Khir Valley, which was the main feeder channel in depositing of the alluvial fan, was deflected after the uplift in a crescent form, flowing towards Bahir Al-Najaf Depression;

- sag ponds: according to Fouad [7, 8], many sag ponds are developed along the Abu Jir-Euphrates Active Fault Zone;

- shutter ridges: according to the constructed model landforms associated with active strike-slip faulting by Keller and Pinter [26], both cliffs of Tar Al-Say'ed and Tar Al-Najaf can be considered as shutter ridges;

- pressure ridges: according to the constructed model landforms associated with active strike-slip faulting by Keller and Pinter [26], the ridge which forms the eastern limit of the Zahra Formation (Fig. 3), west of the alluvial fan, can be considered as a pressure ridge.

\subsection{Historical Evidence}

It is well known that the Euphrates River has changed its course, continuously eastwards. In the involved area, particularly in front of the Karbala-Najaf
Alluvial Fan, the continuous deposition of the fan has shifted the course of the Euphrates River towards east (Figs. 7, 8 and 10).

The following statement is quoted from the Encyclopedia Britannica [27] concerning the shift of the course of the Euphrates River: "Pliny writing in the first century A.D. says that the Euphrates originally had its own mouth and within historical times, the lower course of the river has changed considerably. The shore line at the end of glacial times appears to have been near hit. Below this point, the river has tended to move westwards, the old channel in Sumerian times corresponding more or less to modern Shatt al-Nil, while today the river shows a tendency, so far more or less overcomes, to desert its bed which passes the ruins of Babylon, the Hilla branch, and to follow a yet more westerly channel, the Hindiya branch".

Another historical evidence for shifting of the course of the Euphrates River and the presence of Bahir Al-Najaf Depression, which was filled by fresh water, at the past time, indicating direct contact with the river, is stated hereinafter: "The Arakhtu, or 'river of Babylon', flowed past the southern side of the city, and to the southwest of it on the Arabian bank lay the great inland freshwater sea of Najaf, surrounded by red sandstone cliffs of considerable height, 40 miles (64 $\mathrm{km}$ ) in length and 35 in breadth in the widest part. Above and below this sea, from Borsippa to Kufa, extends the famous Chaldean marshes, where Alexander the Great was nearly lost" (internet data).

\subsection{Present Day Form of Tar Al-Say'ed and Tar Al-Najaf}

The shape of the Karbala-Najaf Alluvial Fan was not what it does appear nowadays, which represents the shape of both Tar Al-Say'ed and Tar Al-Najaf. During the deposition of the alluvial fan, and before the uplifting, which had terminated the deposition, the shape of the alluvial fan was wider than it is now, especially near to the apex area, giving perfect fan shape of delta type. After the uplift, and appearance of 
the two cliffs, Tar Al-Say'ed started to suffer from undercut erosion by Al-Razzazah Lake, due to water agitation and wave actions, giving a crescent shape to the extreme part of the cliff (Fig. 10). Even the end of the cliff (Point 1, in Fig. 10) had suffered from the erosion of the Euphrates River, in its ancient course (AER, in Fig. 10), therefore, it does not look like the end of Tar Al-Najaf (Point 2, in Fig. 10). Moreover, a valley which runs parallel to the cliff had and is still undercutting the cliff due to side erosion.

Tar Al-Najaf also had suffered from undercut erosion by Al-Khir Valley (Figs. 4, 5 and 9), which was extremely large carrying huge amount of water during the Pleistocene, otherwise, the valley would not be able to deposit a fan with length of $64 \mathrm{~km}$, thickness of $8 \sim 15$ $\mathrm{m}$, and without any interruption, as it is evidenced from being a single stage alluvial fan [16].

Nowadays, both of Tar Al-Say'ed and Tar Al-Najaf suffer from toppling of large blocks. Both cliffs are retreating continuously causing more thinning of the apex of the fan at Al-Lisan area which has height of about $3 \mathrm{~m}$ only (Figs. 4, 5 and 9). Moreover, toppling and rock fall are active mass movements, which both cliffs suffer from along their whole length.

The top surface of the alluvial fan has also lost its characteristic due to erosional processes and cultivation activities. However, the main feeder channel is still visible with tens of beheaded streams (Figs. 9 and 10) [26].

\subsection{Age Estimation}

Because no numerical age determination is available to the authors, therefore, "exposure dating method" [26] is used in this study to estimate the age of the two cliffs. The age of the Karbala-Najaf Alluvial Fan is estimated to be Early - early Late Pleistocene, as it is the case of almost all alluvial fans in Iraq [11, 22, 23, 28]. The two cliffs are younger than the alluvial fan, because the sediments of the fan cover the top of the two cliffs, therefore, the age of the cliffs is estimated to be upper Late Pleistocene- early Holocene, or most likely early
Holocene. Some prehistoric settlements in the caves of Tar Al-Sayed indicate their presence during Holocene.

\section{Conclusions}

From this study, the following can be concluded:

- The Karbala-Najaf Alluvial Fan was deposited by Al-Khir Valley, when merging in a large depression due to drop in the gradient of the valley. Consequently, the depression was divided into two parts, to the left is called Al-Razzazah Depression, whereas to the right is called Bahir Al-Najaf;

- The deposition of the alluvial fan was continuously shifting the course of the Euphrates River eastwards, therefore, the sediments in its distal part are interfingering with the flood plain sediments of the Euphrates River;

- The deposition of the alluvial fan was terminated due to an uplift in the area (a neotectonic movement), which is attributed to the activity of the $\mathrm{Abu}$ Jir-Euphrates Fault Zone and Al-Khir Valley has shifted its course towards Bahir Al-Najaf (depression);

- The uplift has caused elevation of the two cliffs, which are covered by alluvial fan sediments;

- The two cliffs had and are still suffering from retreating due to lateral (undercut) erosion by wave actions in Al-Razzazah Depression, towards the left, and Al-Khir Valley, towards the right of the alluvial fan;

- Originally, the width of the alluvial fan in the apex area and almost two thirds of the fan's length towards its distal part were wider than the width nowadays;

- Some geomorphological and structural forms are present in the involved area, like springs located along a straight line, sag pond, deflected drainage, shutter ridges and pressure ridges;

- The age of both cliffs is estimated to be upper Late Pleistocene-early Holocene.

\section{References}

[1] Ghalib, A. A. 1988. "Study the Geomorphology of Najaf Plateau." M.Sc. thesis, University of Baghdad.

[2] DAWN.COM. 2008. "Iraq Lake Dying a Slow Death." 
Accessed January 20, 2015. http://www.dawn.com/news/ 821110/iraq-lake-dying-a-slow-death.

[3] Hamza, N. M. 1997. Geomorphological Map of Iraq, Scale 1:1,000,000. Baghdad: GEOSURV (Iraq Geological Survey).

[4] Barwari, A. M., Yacoub, S. Y., and Buni, T. J. 2003. Quaternary Sediments Map of Iraq, Scale 1:1,000,000. Baghdad: GEOSURV.

[5] Sissakian, V. K., and Ibrahim, F. A. 2005. Geological Hazards Map of Iraq, Scale 1:1,000,000. Baghdad: GEOSURV.

[6] Al-Khateeb, A. A. G., and Hassan, K. M. 2005. Detailed Geological Survey for Mineral Exploration in Karbala-Najaf Area. GEOSURV library report No. 2891.

[7] Fouad, S. F. A. 2004. "Contribution to the Structure of Abu Jir Fault Zone, West Iraq." Iraqi Geological Journal $32 \& 33: 63-73$.

[8] Fouad, S. F. 2007. "Tectonic and Structural Evolution of the Iraqi Western Desert." Geology of Iraqi Western Desert, Iraqi Bulletin of Geology and Mining 1: 29-50.

[9] Fouad, S. F. 2010. "Tectonic and Structural Evolution of the Mesopotamia Foredeep, Iraq." Iraqi Bulletin of Geology and Mining 6 (2): 41-53.

[10] Fouad, S. F., and Sissakian, V. K. 2011. "Tectonic and Structural Evolution." Geology of the Mesopotamia Plain, Iraqi Bulletin of Geology and Mining 4: 33-46.

[11] Yacoub, S. Y. 2011. "Geomorphology." Geology of the Mesopotamia Plain, Iraqi Bulletin of Geology and Mining 4: 7-32.

[12] Ma'ala, K. A. 2009. "Geomorphology." Geology of the Southern Desert, Iraqi Bulletin of Geology and Mining 2: 7-33.

[13] Fouad, S. F. 2012. Tectonic Map of Iraq, Scale 1:1,000,000. 3rd ed.. Baghdad: GEOSURV.

[14] Sissakian, V. K., and Fouad, S. F. 2012. Geological Map of Iraq, Scale 1:1,000,000. 4th ed.. Baghdad: GEOSURV.

[15] Al-Basrawi, N. H., and Al-Jibouri, H. 2013. Hydrogeological Map of Iraq, Scale 1:1,000,000. 2nd ed.. Baghdad: GEOSURV.

[16] Sissakian, V. K., and Abdul Jab'bar, M. F. 2014. "Classifications of Alluvial Fans in Iraq." Iraqi Bulletin of
Geology and Mining 10 (3). (in press)

[17] Bull, W. B. 1991. Geomorphic Responses to Climate Change. Oxford: Oxford University Press.

[18] Ritter, D. F., Kochel, R. C., and Miller, J. R. 2002. Process Geomorphology. USA: McGraw Hill Higher Education.

[19] USGS (United States Geological Survey). 2004. "Desert Working Group, Knowledge, Science Incorporation, Alluvial Fans.” USGS. Accessed December 3, 2014. http://greatbasin.wr.usgs.gov/LWG/LWGdetail.asp?State $=\mathrm{ID} \& \mathrm{LWG}=12$.

[20] Given, J. 2009. "The Climatic Paradigm: The Correlation of Climate to Dry Land Alluvial Fan Evolution and Morphology." Accessed December 2, 2014. www.scirp.org/reference/ReferencesPapers.

[21] NASA (National Aeronautics and Space Administration). 2009. "Geomorphology from Space, Fluvial Landforms, Chapter 4.” NASA. Accessed December 2, 2014. http://en.wikipedia.org/wiki/Alluvial_fan.

[22] Yacoub, S. Y. 2011. "Stratigraphy." Geology of the Mesopotamia Plain, Iraqi Bulletin of Geology and Mining 4: 47-82.

[23] Sissakian, V. K., and Abdul Jab'bar, M. F. 2013. "Alluvial Fans of the Hab'bariyah Depression, Iraqi Western Desert." Iraqi Bulletin of Geology and Mining 9 (2): 27-45.

[24] Wikipedia. 2014. “Lake Milh.” Wikipedia Accessed December 10, 2014. http://en.wikipedia.org/wiki/Lake_ Milh.

[25] Zaeen, A. A. 2012. "Using Remote Sensing Techniques to Monitor and Evaluate the Water Cover in Al-Razzazalake: Iraq at Different Periods." Iraqi Journal, Physics 10 (17): 45-52.

[26] Keller, E. A., and Pinter, N. 2002. Active Tectonics, Earthquakes, Uplift and Landscape. 2nd ed.. USA: Prentice Hall.

[27] Encyclopedia Britannica. 2011. "Mesopotamia, Geography." Encyclopedia Britannica. Accessed December 2, 2014. http://gluedideas.com/EncyclopediaBritannica-Volume-8-Part-2-Edward-Extract/Central-Eur ope.html.

[28] Sissakian, V. K. 2011. "Alluvial Fans of Sinjar Mountain, Northwest Iraq." Iraqi Bulletin of Geology and Mining 7 (2): 9-26. 